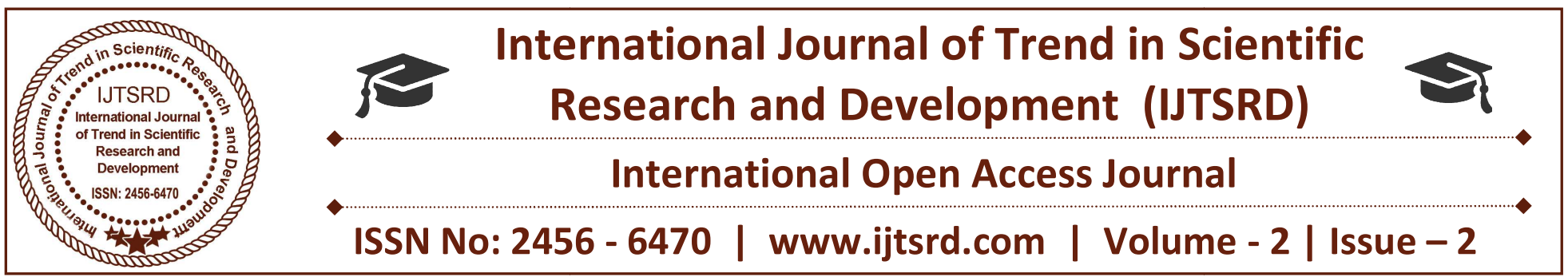

\title{
Leadership: The Essence of Sikhism
}

\author{
Navneet Kaur \\ Assistant Professor, School of Commerce and Management, \\ GSSDGS Khalsa College, Patiala, Punjab, India
}

\begin{abstract}
The Sikh religion being the most modern and scientific religion is unique as far as its content, philosophy and fait are concerned. It is a general believe that faith and logic cannot go hand in hand, but Sikh religion as such has no threat from science, rationality, logics and objectivity. This religion has evolved many leaders who showed their inbuilt leadership styles in their own ways, right from the time of its evolution. Much of literature till now has showed the compatibility between Sikh religion and leadership values. This research paper highlights some common characters of a Sikh, as mentioned in Guru Granth Sahib Ji, with that of an ideal leader. The main aim of the study is to explore how Guru Prophets and the Sikh followers showed their strength, courage and leadership qualities for the community and set an example for others. An attempt has also been made to give a message to the Sikhs to imbibe in them the fading away Guru's message for the transformation of the community as a whole.
\end{abstract}

Keywords: Shri Guru Granth Sahib Ji, Leadership, Guru Prophets, Sikhism

\section{INTRODUCTION}

Leadership is an ability or talent of "leading" or inspiring the individuals, group of people or an organization to achieve their mission by having a vision. While talking professionally, leaders play a key role in the achieving the objectives of an organization and to maintain an ethical work culture. Ethical leaders provide subordinates with voice, ask for and listen to their input, and allow them to share in decision making on issues that concern their tasks
(Brown, Trevino and Harrison, 2005). A good leader fixes higher standards for his followers and at the same time also ensures their commitment to those standards.

Different authors defined leadership in various other verdicts:

"Leadership is the ability to see a problem and be the solution. So many people are willing to talk about problems or can even empathize, but not many can see the problem or challenge and rise to it. It takes a leader to truly see a problem as a challenge and want to drive toward it. That is what causes people to want to follow, and a true leader has a following." - Andrea Walker-Leidy, owner, Walker Publicity Consulting.

"A leader is someone [who] leads by example and has the integrity to do the right thing even when it is not popular. A good leader has positive influence over others, inspiring them to become a better person and example for others to model their life against, as well." - Mark Little, founder and president, Diversified Funding.

Sikhism, or Sikhi (Sikh being a disciple or a learner), is a religion with a strong belief in a single God, the origination of which was in the Punjab region of South Asia during the period of 15 th century. Sikhism is the ninth-largest religion in the world. What makes Sikhs significant is not their numbers but their contribution in the different spheres. The core principles as per Sikh ideology are equality (social justice), liberty (activism of human rights) and selfless service (a gratitude to the divine creator, by praising and serving its creation). The Sikh religion being the youngest and newest of all 
independent religions of India- nearly 500 years old, most modern and scientific religion is unique in its terms of its content, philosophy and faith. It is a general believe that faith and logic cannot go hand in hand, but Sikh religion, as portrayed by Guru Granth Sahib Ji, the holy book of Sikhs, has no threat from science, rationality, logics and objectivity.

\section{REVIEW OF LITERATURE:}

Kaur and Manhas(2015) in their research paper "Teachings of Shri Guru Granth Sahib Ji and Ethos in Management" focused on evalualting the ethics and ethos in management and the implementation of Shri Guru Granth Sahib Ji in management. According to them, ethos in today's management has six basic principles - Immense Potential Power, Holistic Approach, Equal Importance to Subjectivity, Karma Yoga, Yogah Karmasu Kaushalam (Yoga means excellence at work and Kaushalam means doing work with devotion) and cooperation. the researchers are of the view that with more attention to management ethics in organization, there is a need to derive the message conveyed in Guru Granth Sahib Ji so that the corporate scandals and unethical behavior being in trend in organizations can be reversed and there is a need for people to put Gurbani into practical shape in their lives.

Kaur and Ubha, in their research work "Leadership Wisdom: Lessons from Sikhism" aimed to highlight the great philosophy of Shri Guru Granth Sahib Ji and imbibe its message in the materialistic business world. The basic aim of the researchers is to formulate and systematize the wisdom of Guru Granth Sahib Ji in the field of Leadership Ethics of the business organizations and to explore different leadership ethics congruent to Shri Guru Granth Sahib Ji. According to the research, there are six core ethical leadership values as treasured in Shri Guru Granth Sahib Ji- Integrity, Compassion, Equity, Tolerance, Selflessness and Stewardship.

Singh and Singh (2006) in their research work "Sikh Leadership: Established Ideals and Diasporic Reality" clearly focused on imparting the Sikh culture to masses by understanding and admiring the Guru Prophets' lives. According to them, Sikhism, as portrayed by Shri Guru Granth Sahib Ji, and its mission is based on three main principles of Sikh leadership model: Equality, Liberty and Self Sacrifice. the researchers were strongly in belief that the framework set by Sikh Gurus and the divine qualities postured in Shri Guru Granth Sahib Ji can be the best source of inspiration for the Sikh community to transform them once again.

\section{SIKH WISDOM AND LEADERSHIP VALUES:}

Guru Granth Sahib Ji preaches the virtues of love, devotion, truthful living, liberty, equality, justice, humanity and faith, which and they are considered as the core values of ethical leadership. On the other hand, lust, pleasure, greed, anger and attachment, considered to be the roots of unethical leadership. It is rightly being said that leaders are born, not made. Sikhism is an essence of leadership. This religion has given birth to many great leaders, right from the time of Guru prophets'till now, who lead this religion and the disciples setting an example of self sacrifice themselves. The Guru -Prophets played this role for 239 years, before passing this duty to the eternal Guru, Guru granth sahib ji, and to the Khalsa Panth, which is a collective leadership of Sikh community established by the tenth Guru, Guru Gobind Singh Ji.

Over the last five centuries, the Sikh nation has been led by numerous personalities. The Gur -Prophets guided the community over a period of 1469-1708 C.E. The Gurus emphasized a balance between leading for the benefit of others and maintaining a sense of self sovereignty (Singh and Singh, 2006). Guru Amardas ji, the third Guru, in his teachings (Sri Guru Granth Sahib, 1088), clearly referred to that the leaders who are driven by materialistic royalty are unworthy of noble recognition. Generally speaking, the divine qualities of the supreme power, as posed by Gurus in the bani of Sri Guru Granth Sahib Ji are more or less, the desirable qualities of a good leader to a greater extent. One of them points out the very divine quality of fearlessness, as mentioned in the very opening verse of Guru Granth Sahib Ji, named as 'Nirbhau' Similar are the characteristics like creativity, unbiasness, honesty etc. According to the Gurus, an ideal leader, besides having the wordly knowledge, must also possess divine wisdom.

\section{THE MAGNUM OPUS OF SIKH RELIGION:}

Gathering and seeking harmony is the key factor of Sikh community. No individual leader can make Sikh related decisions. It is evident from the Sikh history that collective interest was always preferred over self interest. Collective interest was not only confined to the perimeter of Sikhs. For instance, when Kashmiri 
Pandits approached Guru Teg Bahadur Ji, the ninth Guru, and begged him to protect hindus from the orders of Aurangzeb regarding forceful conversions of their religion, the Guru fought to his martyrdom revealing his strong belief in freedom of religion. This incidence portrayed a different style of leadership followed by the $9^{\text {th }}$ Guru. Another relevant evidence of a unique leadership was potrayed by Guru Gobind Singh Ji, the tenth Guru. The concept of introducing 'Panj Pyaras', the five dedicated Sikhs, left no space to rely on any single individual. The 'behind the stage' idea was that five people are less likely to become corrupt than a single individual. Guru Gobind Singh was a saint as well as a soldier for his followers, who were inspired by him to fight maltreatment in order to reinstate Justice, peace and righteousness. His teachings are very scientific and suitable that he never treated himself as god or "the son of god", rather he used the word 'slave' or 'servant' for himself.

Maharaja Ranjit Singh was great warrior and a fearless soldier of his time. After many campaigns his rivals accepted him as a leader and he played a great role to unite the Sikh wing into one state. He treated Hindu and Muslim equally. Maharaja Ranjit Singh was well known for filling the leadership positions in his Darbar with men of varied religions. Ranjit Singh declared that his one eye gave him ability to see everyone equally.

Hari Singh Nalwa, a man reputed as a truly legendary military leader, was known for his exceptional courage to defeat the larger armies. He was the commander in chief of the Sikh empire's army. He became the only man in history to take the Khyber Pass-the Mountain path that connects Afghanistan and Pakistan. It truly showed his strategic brilliance.

Banda Singh Bahadur was Sikh military leader who carried an offensive war against the Mughal rulers of India. Armed with the blessings and authority of Guru Gobind Singh, he assembled and led a fighting force against the Mughal Empire.

Sikh history doesn't remain untouched with contribution of women. Mai Bhago was a lady with bravery, courage, truth \& faith. She had the ability to lead 40 Sikh solider against the Mughals. By inspiring the people she built an army and took the oath to fight and not to withdraw. She was the only survivor of the battle of Muktsar(Khidrana).

\section{CONCLUSION:}

Equality, Liberty and Self Sacrifice are the three utmost Principles of an ideal Sikh leadership model, which truly defines the various aspects of a sikh's character. But the bitter truth is that it is extremely difficult to influence and amend the prevailing attitudes. Over the last few centuries, the vision of a Sikh leader, as demonstrated by the Guru Prophets has lost somewhere. This lead the Sikh community to face many problems over a period of time. Due to the lack of value-driven leadership, the Sikh nation has been ineffective in dealing with various problems. Moreover, a little effort has been taken to interpret and convey Guru's message to the nation. The ideal Sikh leader would be able to recognize, address and resolve any and all issues relating to the community at large (Singh and Singh, 2006). The need of an hour is to discover few good leaders who can trigger confidence within the Sikh community so that they can remember the Guru's message through the Prophets' achievements, sacrifices and martyrs, and can transform themselves and the community once again.

\section{BIBLIOGRAPHY:}

1. kaur, Manhas (2015), " Teachings of Shri Guru Granth Sahib Ji and Ethos in Management", International Journal of Management Sciences and Business Research, vol 4, issue 6, pp.75-83 online available at : http://www.ijmsbr.com/Volume\%204\%20Issue\% 206\%20Paper\%2011.pdf assessed on 2.9.2016

2. Singh, Singh (2006), "Sikh Leadership: Established Ideals and Diasporic Reality" Teaching Theology and Religion, vol. 9 no. 2, pp 133-138 online available

at: http://digitalcommons.trinity.edu/cgi/viewcontent.cgi? article $=1005 \&$ context $=$ relig_faculty

3. kaur, Ubha, "Leadership Widom: Lessons from Sikhism" online available at: http://www.wbiconpro.com/704-Dharminder.pdf last assessed on 3.9.2016

4. Helmrich (2016) Business News Daily (online) available at:

http://www.businessnewsdaily.com/3647-

leadership-definition.html last assessed on 3.9.2016

5. International Encyclopedia of Marriage and Family (2003) online available at : 
http://www.encyclopedia.com/topic/Sikhism.aspx

last assessed on 1.9.2016

6. Nicole Fallon Taylor (2016), Business News

Daily (online) available at :

http://www.businessnewsdaily.com/2730-

leadership.html last assessed on 5.9.2016

7. Wikipedia, the free encyclopedia (online) available at

https://en.wikipedia.org/wiki/Sikhism

8. http://shodhganga.inflibnet.ac.in/bitstream/10603/ 13572/12/12_chapter\%205.pdf

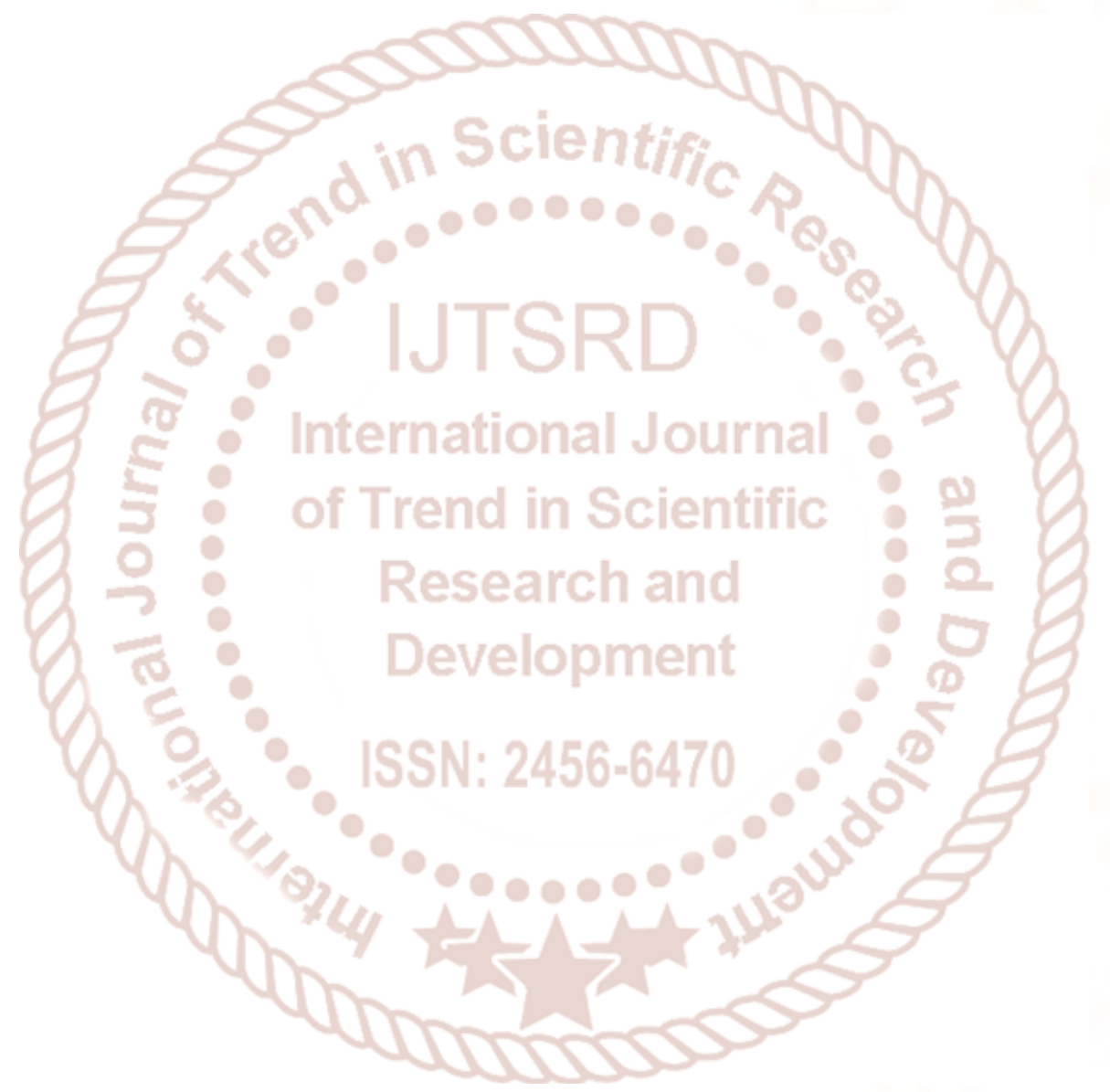

